\title{
Erratum
}

\section{Erratum to: A way of decoupling gravitational sources in pure Lovelock gravity}

\author{
Milko Estrada ${ }^{\mathrm{a}}$ \\ Departamento de Física, Facultad de ciencias básicas, Universidad de Antofagasta, Casilla 170, Antofagasta, Chile
}

Received: 13 May 2020 / Accepted: 16 May 2020 / Published online: 29 June 2020

(C) The Author(s) 2020

\section{Erratum to:}

Eur. Phys. J. C (2019) 79:918

https://doi.org/10.1140/epjc/s10052-019-7444-6

The original version of this article unfortunately contains a mistake. The acknowledgement section of the above article should have been included at the end of the article (after section 6). The correct acknowledgements are as follows:

Acknowledgements Milko Estrada acknowledge to the Doctorado en Física, mención Física Matemática (Ph.D. in Physics) program of the Universidad de Antofagasta, Chile (program to which the author belongs).

Open Access This article is licensed under a Creative Commons Attribution 4.0 International License, which permits use, sharing, adaptation, distribution and reproduction in any medium or format, as long as you give appropriate credit to the original author(s) and the source, provide a link to the Creative Commons licence, and indicate if changes were made. The images or other third party material in this article are included in the article's Creative Commons licence, unless indicated otherwise in a credit line to the material. If material is not included in the article's Creative Commons licence and your intended use is not permitted by statutory regulation or exceeds the permitted use, you will need to obtain permission directly from the copyright holder. To view a copy of this licence, visit http://creativecomm ons.org/licenses/by/4.0/.

Funded by SCOAP ${ }^{3}$.

The original article can be found online at https://doi.org/10.1140/ epjc/s10052-019-7444-6.

a e-mail: milko.estrada@ua.cl (corresponding author) 